\title{
ON A NEW GENERALIZATION OF MARTINS' INEQUALITY
}

\author{
FENG Qi AND SENLIN GUO
}

Abstract. Let $n, m \in \mathbb{N}$ and $\left\{a_{i}\right\}_{i=1}^{n+m}$ be an increasing, logarithmically concave, positive, and nonconstant sequence such that the sequence $\left\{i\left[\frac{a_{i+1}}{a_{i}}-1\right]\right\}_{i=1}^{n+m-1}$ is increasing. Then the following inequality between ratios of the power means and of the geometric means holds:

$$
\left(\frac{1}{n} \sum_{i=1}^{n} a_{i}^{r} / \frac{1}{n+m} \sum_{i=1}^{n+m} a_{i}^{r}\right)^{1 / r}<\frac{\sqrt[n]{a_{n} !}}{\sqrt[n+m]{a_{n+m} !}}
$$

where $r$ is a positive number, $a_{n}$ ! denotes the sequence factorial defined by $\prod_{i=1}^{n} a_{i}$. The upper bound is the best possible.

Mathematics subject classification (2000): 26D15, 26E60.

Key words and phrases: Martins's inequality, Alzer's inequality, König's inequality, increasing sequence, logarithmically concave, ratio, power mean, geometric mean.

\section{REFERENCES}

[1] H. AlzER, On an inequality of H. Minc and L. Sathre, J. Math. Anal. Appl. 179 (1993), 396-402.

[2] P. S. Bullen, A Dictionary of Inequalities, Pitman Monographs and Surveys in Pure and Applied Mathematics 97, Addison Wesley Longman Limited, 1998.

[3] CH.-P. ChEN AND F. QI, Notes on proofs of Alzer's inequality, Octogon Math. Mag. 11 (2003), no. 1, 29-33.

[4] T. H. Chan, P. GAO AND F. QI, On a generalization of Martins' inequality, Monatsh. Math. 138 (2003), no. 3, 179-187. RGMIA Res. Rep. Coll. 4 (2001), no. 1, Art. 12, 93-101; Available online at URL: http://rgmia.vu.edu.au/v4n1.html.

[5] Ch.-P. Chen, F. QI, P. CERone, AND S. S. DRAGOMIR, Monotonicity of sequences involving convex and concave functions, Math. Inequal. Appl. 6 (2003), no. 2, 229-239. RGMIA Res. Rep. Coll. 5 (2002),no. 1, Art. 1, 3-13; Available online at URL: http://rgmia.vu. edu.au/v5n1.html.

[6] N. ElezoviĆ AND J. PeČARIĆ, On Alzer's inequality, J. Math. Anal. Appl. 223 (1998), 366-369.

[7] B.-N. GuO AND F. QI, An algebraic inequality, II, RGMIA Res. Rep. Coll. 4 (2001), no. 1, Art. 8, 55-61; Available online at URL: http://rgmia.vu.edu.au/v4n1.html.

[8] B.-N. GUO AND F. QI, Inequalities and monotonicity for the ratio of gamma functions, Taiwanese J. Math. 7 (2003), no. 2, 239-247.

[9] B.-N. GUO AND F. QI, Inequalities and monotonicity of the ratio for the geometric means of a positive arithmetic sequence with arbitrary difference, Tamkang. J. Math. 34 (2003), no. 3, 261-270.

[10] B.-N. GUO AND F. QI, Monotonicity of sequences involving geometric means of positive sequences with monotonicity and logarithmical convexity, Math. Inequal. Appl. 9 (2006), no. 1, 1-9.

[11] H. KÖNIG, Eigenvalue Distribution of Compact Operators, Birkhaüser, Basel, 1986.

[12] J.-Ch. KuAng, Some extensions and refinements of Minc-Sathre inequality, Math. Gaz. 83 (1999), 123-127.

[13] ZH. LIU, New generalization of H. Alzer's inequality, Tamkang J. Math. 34 (2003), no. 3, 255-260.

[14] J. S. MARTINS, Arithmetic and geometric means, an application to Lorentz sequence spaces, Math. Nachr. 139 (1988), 281-288. 
[15] J. PeČarić, F. Proschan, And Y. L. Tong, Convex Functions, Partial Orderings, and Statistical Applications, Mathematics in Science and Engineering 187, Academic Press, 1992.

[16] F. QI, An algebraic inequality, J. Inequal. Pure Appl. Math. 2 (2001), no. 1, Art. 13; Available online at URL: http: / / jipam.vu.edu.au/article.php?sid=129. RGMIA Res. Rep. Coll. 2 (1999), no. 1, Art. 8, 81-83; Available online at URL: http://rgmia.vu.edu.au/v2n1.html.

[17] F. QI, Generalizations of Alzer's and Kuang's inequality, Tamkang J. Math. 31 (2000), no. 3, 223-227. RGMIA Res. Rep. Coll. 2 (1999), no. 6, Art. 12, 891-895; Available online at URL: http://rgmia.vu.edu.au/v2n6.html.

[18] F. QI, Generalization of H. Alzer's inequality, J. Math. Anal. Appl. 240 (1999), no. 1, 294-297.

[19] F. QI, Inequalities and monotonicity of the ratio for the geometric means of a positive arithmetic sequence with unit difference, Internat. J. Math. Ed. Sci. Tech. 34 (2003), no. 4, 601-607. Austral. Math. Soc. Gaz. 30 (2003), no. 3, 142-147. RGMIA Res. Rep. Coll. 6 (2003), Suppl., Art. 2. Available online at URL: http://rgmia.vu.edu.au/v6 (E) .html.

[20] F. QI, Inequalities and monotonicity of sequences involving $\sqrt[n]{(n+k) ! / k !}$, Soochow J. Math. 29 (2004), no. 4, 353-361. RGMIA Res. Rep. Coll. 2 (1999), no. 5, Art. 8, 685-692; Available online at URL: http://rgmia.vu.edu.au/v2n5.html.

[21] F. QI, On a new generalization of Martins' inequality, RGMIA Res. Rep. Coll. 5 (2002), no. 3, Art. 13, 527-538; Available online at URL: http://rgmia.vu.edu.au/v5n3.html.

[22] F. QI AND L. DEBNATH, On a new generalization of Alzer's inequality, Internat. J. Math. Math. Sci. 23 (2000), no. $12,815-818$.

[23] F. QI AND B.-N. GUO, An inequality between ratio of the extended logarithmic means and ratio of the exponential means, Taiwanese J. Math. 7 (2003), no. 2, 229-237.

[24] F. QI AND B.-N. GuO, Monotonicity of sequences involving convex function and sequence, Math. Inequal. Appl. 9 (2006), no. 2, 247-254. RGMIA Res. Rep. Coll. 3 (2000), no. 2, Art. 14, 321-329; Available online at URL: http://rgmia.vu .edu .au/v3n2.html.

[25] F. QI AND B.-N. GUO, Monotonicity of sequences involving geometric means of positive sequences with logarithmical convexity, RGMIA Res. Rep. Coll. 5 (2002), no. 3, Art. 10, 497-507; Available online at URL: http://rgmia.vu.edu.au/v5n3.html.

[26] F. QI AND B.-N. GUO, Some inequalities involving the geometric mean of natural numbers and the ratio of gamma functions, RGMIA Res. Rep. Coll. 4 (2001), no. 1, Art. 6, 41-48; Available online at URL: http://rgmia.vu.edu.au/v4n1.html.

[27] F. QI AND Q.-M. LuO, Generalization of H. Minc and J. Sathre's inequality, Tamkang J. Math. 31 (2000), no. 2, 145-148. RGMIA Res. Rep. Coll. 2 (1999), no. 6, Art. 14, 909-912; Available online at URL: http://rgmia.vu.edu.au/v2n6.html.

[28] F. QI, B.-N. GUO, AND L. DEBNATH, A lower bound for ratio of power means, Internat. J. Math. Math. Sci. 2004 (2004), no. 1, 49-53. RGMIA Res. Rep. Coll. 5 (2002), no. 4, Art. 2; Available online at URL: http://rgmia.vu.edu.au/v5n4.html.

[29] F. QI AND N. TOWGHI, Inequalities for the ratios of the mean values of functions, Nonlinear Funct. Anal. Appl. 9 (2004), no. 1, 15-23.

[30] J. A. SAMPaIo Martins, Inequalities of Rado-Popoviciu type, In: Marques de Sá, Eduardo (ed.) et al. Mathematical studies. Homage to Professor Doctor Luís de Albuquerque. Coimbra: Universidade de Coimbra, Faculdade de Ciências e Tecnologia, Departamento de Matemática, (1994), 169-175.

[31] J. SÁNDOR, On an inequality of Alzer, J. Math. Anal. Appl. 192 (1995), 1034-1035.

[32] J. SÁNDOR, On an inequality of Bennett, General Mathematics (Sibiu), 3 (1995), no. 3-4, 121-125.

[33] N. TOWGHI AND F. QI, An inequality for the ratios of the arithmetic means of functions with a positive parameter, RGMIA Res. Rep. Coll. 4 (2001), no. 2, Art. 15, 305-309; Available online at URL: http://rgmia.vu.edu.au/v4n2.html.

[34] J. S. UME, An elementary proof of H. Alzer's inequality, Math. Japon. 44 (1996), no. 3, 521-522.

[35] Z.-K. Xu, On further generalization of an inequality of H. Alzer, Zhējiāng Shifàn Dàxué Xuébào Zìrăn Kēxué Băn (J. Zhejiang Norm. Univ. (Nat. Sci.)) 44 (2002), 365-373. (Chinese)

[36] Z.-K. XU AND D.-P. XU, A general form of Alzer's inequality, Comput. Math. Appl. 44 (2002), 365-373. 